\title{
Calculating the Departmental Credit-Hour Cost for Higher Learning Institutions Using Joint Costing and Activity-Based Costing Systems Simultaneously
}

\author{
Saleem Z. Ramadan ${ }^{1} \&$ Mahmoud A. Barghash ${ }^{1}$ \\ ${ }^{1}$ Department of Mechanical and Industrial Engineering, Applied Science University, Shafa Badran, Amman, \\ Jordan \\ Correspondence: Saleem Z. Ramadan, Department of Mechanical and Industrial Engineering, Applied Science \\ University, Shafa Badran, 11931, Amman, Jordan. Tel: 967-9911-0835. E-mail: s_ramadan@asu.edu.jo
}

Received: February 12, 2015

Accepted: March 9, 2015

Online Published: April 25, 2015

doi:10.5539/ibr.v8n5p195

URL: http://dx.doi.org/10.5539/ibr.v8n5p195

\begin{abstract}
The question of how to calculate the effective credit hour costs for different departments in Higher Learning Institutions was approached in this paper using Joint Costing and Activity-Based Costing techniques. The cost of the effective credit hour in the higher learning institutions was treated as joint cost problem. The main advantage of joint cost analysis is its ability to handle multiple faculties who are using common resources up to achieve split off so that each faculty has its own separable cost. The departments within the faculty were also treated as joint cost problem as these departments use common resources up to their split off point as well. The Activity-Based Costing system (ABC) then was used because of its ability to allocate the joint costs to the corresponding faculties and departments. Furthermore, the separable costs pertaining the different departments were added to calculate the departments' costs. We suggest that the annual effective departmental credit-hour cost to be calculated by dividing the annual total cost of the department by the annual effective number of credit hours taught in that department. The Knapsack model was applied at each cost level to determine the optimal cost driver set for the Activity-Based costing analysis such that a tradeoff between the precision and the cost of the information obtained from the analysis was reached.

The proposed model was explained using a hypothetical example of a university containing 9 faculties such that the costs incurred for the university were decomposed into four levels: Facility level and it included all the costs that were not directly related to any of the faculties or departments, Product level and it included all the costs that were related to a certain faculty and not related to a specific department within that faculty, Batch level and it included all the costs that were directly related to a specific department, and finally, the Unit level and it included the annual effective number of hours registered in a department. Originally 12 cost drivers were considered for this hypothetical problem, and then a binary programming model utilizing the Knapsack setup was used to select an optimal set of 9 cost drivers such that those who are not selected were combined with the ones that were selected. The results showed that the proposed method offered precise information about the annual departmental credit-hour cost for higher learning institutions.
\end{abstract}

Keywords: joint costing, activity-based costing, higher learning institutions, cost driver optimization, Knapsack problem

\section{Introduction}

In the existing harsh economy, controlling and managing the costs in the higher learning institutions are necessary as many institutions gone into bankruptcy because of their poor control on the overhead costs. A cost management system that provides a quality and timely information to support decision making process should be used by the companies to survive in the market. Several studies showed empirical evidences that Activity-Based Costing ( $\mathrm{ABC}$ ) system has advantages over the traditional costing systems regarding overhead cost in terms of providing timely and quality information and in terms of increasing the effectiveness of the overall process by eliminating unnecessary usage of some resources. (Foster \& Swenson, 1997; McGowan \& Klammer, 1997; Baird et al., 2004; Robert, 1992; Cagwin \& Bouwman, 2002; Innes \& Mictchell, 1997). The essence of these aforementioned studies is that $\mathrm{ABC}$ system has certain traits that make it reliable for cost decision making 
purposes. ABC system has a homogenous cost pool in which all costs that have the same cause are gathered in the same cost pool, thus cost allocation is based on cost causatives. Moreover, the ABC allocates costs based on several levels of cost drivers opposed to usually one level in traditional costing systems. As a consequence of these traits, the output of $\mathrm{ABC}$ is trusted as it provides the management with precise products or services costs.

Since Cooper and Kaplan in 1988, many authors used ABC to develop costing systems for service companies like hospitals, banks, insurance companies, land transportation companies, and hotels to help them survive in their environments as these sectors have to deal with analyzing operating expenses and performing service activities that demand resources (Cagwin \& Bouwman, 2002; Dorota \&Sabina, 2011; Jordi \& Xavier, 2008; Adams, M., 1996; Baykaso \& Kaplano, 2008). In service companies, the cost of the service consists of two main costs: direct labor costs and overhead or indirect costs. Direct labor costs can be easily related to the service whereas overhead costs are hard to trace especially when there are several non-homogeneous services performed in the company. Consequently, overhead cannot be related directly to the individual services.

A number of studies dealt with costing for higher learning institutions, Cropper and Cook, 2000 called upon the universities to adopt more reliable cost management systems to allocate resources precisely. Bourn, 1994 argued that traditional costing systems were not providing adequate information to support decision makers in universities. Goddard and Ooi (1998) and Jarrar et al. (2007) emphasized the need for an effective cost management system in these institutions. Krishnan, 2006 showed that Activity Based Costing can help higher learning institutions to calculate students' costs effectively. Cox et al. (2007) showed how to apply ABC in higher learning institutions utilizing four main activities: teaching, research, service, and administration. They also proposed using $\mathrm{ABC}$ to allocate the salaries of the faculty members to these activities. Ruhupatty et al. (2014) discussed the cost of quality in higher education from the faculty members' perspectives and calculated the cost of quality for administrative activities using $\mathrm{ABC}$ analysis. Carlos (2011) proposed a hybrid ABC-Traditional cost accounting system for social sciences faculties to identify the profitable and non-profitable courses. Acton and Cotton (1997) used ABC to develop a model that used the concepts of both ABC and the Value Based Management. The model attempted to calculate the cost of modules, programs, and research projects.

These studies used ABC system to handle the cost of the higher learning institutions on the level of departments or courses but did not go to the level of departmental credit-hour cost for the higher learning institutions. While in this study, ABC analysis will be used to handle the cost of the higher learning institutions on the level of the departmental credit-hour cost. Moreover, no one in the previous studies treated the effective credit hour cost problem for higher learning institutions as a Joint cost problem. While in this study, the effective credit hour cost problem for higher learning institutions will be treated as joint cost problem. At the split off points, the ABC system will be used to allocate the joint costs to the corresponding faculties and departments. Hence, the joint costing system and the $\mathrm{ABC}$ system will be applied simultaneously to calculate the departmental credit-hour cost for the higher learning institutions. Furthermore, this study will use a cost driver optimization model based on Knapsack setup with a different objective function than the one used in the vast majority of the literature related to $\mathrm{ABC}$ that is based on the objective function suggested by Babad and Balachandran (1993). Unlike them, the objective function in this study will use the value of the cost driver as a proxy for the precision of the information. To the best of the authors' knowledge, this combination of ABC, Joint cost, Departmental credit-hour cost, and the objective function of the cost driver optimization model was not used before in literature to handle the cost of the higher learning institutions.

Joint costing system will be used for the reason that the higher learning institutions contain students from different faculties. Those students are using the common institution resources like registrar office, financial department, student's affairs, and university compulsory courses. At split off point, the students in each faculty will have their own resources like faculty compulsory courses and faculty free labs. Furthermore, students in the same faculty can be also treated as joint cost problem. Those students in the same faculty use the common faculty resources. At the split off point, the students in each department within the faculty will have their own resources like department compulsory courses and department labs. These overhead joint costs can be allocated at their split off points to the different faculties and departments using ABC analysis instead of using the traditional allocation methods such as Physical Quantities, Sales Value, or Constant Gross Margin Percentage methods. The logic behind using the $\mathrm{ABC}$ for the cost of learning process in the higher learning institutions is that the indirect costs of the university cannot be traced easily to the different faculties and the faculty indirect costs cannot be traced easily to their departments. This calls upon using ABC analysis for allocating the indirect costs based on causal activities by identifying direct links between the cost and the cost objects, the matter that enhances the quality of information provided for managers and thus enhances their decisions. 
Unfortunately, the enhancement of the quality of information accompanied with increase in the information cost. Cooper (1989) emphasized the importance of the proper choice of the number of costs drivers and the type of cost drivers used to aggregate the different overhead costs. In a later article in 1990, Cooper suggested a method to determine the number of required cost drivers based on the desired accuracy in the cost and based on the degree of homogeneity in the cost objects mixed. He suggested that as the cost objects mixed become more diverse, the number of cost drivers should increase. He also suggested that small cost activities don't required a separate cost drivers. Cooper also mentioned the degree of correlation between the consumption of the activities and the drivers as one of the factors that affect the number of drivers needed.

Since then some studies dealt with the problem of Cost Drivers Optimization (CDO). Babad, and Balachandran, 1993 proposed an Integer programming to solve the CDO using greedy algorithm. Alan and Gupta 1996 solved the CDO using Genetic algorithm model. Casten (2001), used a similar approach used in Babad and Balachandran (1993) to approach the CDO problem. Other authors used other approaches to solve the CDO problem. For example, Datar et al. (1993) and Wang et al. (2009) used regression models to solve the problem.

The essence of all these studies is to have a tradeoff between the cost and the accuracy of information in ABC system. In one hand, small number of activities will result in low information cost, but unfortunately, low information accuracy. On the other hand, large number of activities will result in high information accuracy, but unfortunately, high information cost. So the CDO problem dealt with determining the number of cost drivers along with which cost drivers are needed to have the highest precision while keeping the cost of information at manageable levels. In this study, binary programming utilizing Knapsack model will be proposed and used to find the optimal set of cost drivers. Unlike the objective function used in Babad and Balachandran (1993), the objective function of the Knapsack model will use the value of the cost driver as a proxy for the precision of the information.

The mathematical formulation for the $\mathrm{CDO}$ problem proposed in this study is as follows:

$$
\begin{gathered}
\operatorname{Max} \sum_{i=1}^{N_{C L}} A_{C L_{i}} x_{i} \\
\text { s.t } \\
\sum_{i=1}^{N_{C L}} D_{C L_{i}} x_{i} \leq B_{C L} \\
1 \leq \sum_{i=1}^{N_{C L}} x_{i} \leq n_{C L} \\
B_{C L} \geq \min \left(D_{C L_{i}}\right) \\
x_{i} \text {, binary }
\end{gathered}
$$

Where $C L$ is the cost level under consideration that can take one of the four values: Facility, Product, Batch, or Units level. $N_{C L}$ is the original number of cost drivers for the $C L$ under consideration. $A_{C L_{i}}$ is the cost of the original cost drivers for the $C L$ under consideration. $x_{i}$ is binary decision variable to indicate including (value 1) or excluding (value 0 ) the cost driver from the original cost drivers set at the $C L$ under consideration. $D_{C L_{i}}$ is cost of gathering the information for the original cost drivers for the $C L$ under consideration.

Equation 1 can be seen as a proxy for the precision of the information. This is inspired by the guidelines suggested by Cooper 1990 about selecting the optimal cost driver set. The reasoning for this is that as the value of the cost driver, $A_{C L_{i}}$, increases, the importance of including it in the final optimal cost driver set increases. For cost drivers with small values, the mistake in allocating their values will not distort the results as if there is a mistake in allocating the cost of a cost driver with higher value. So the cost of the cost driver can be used as a proxy for the precision of the results. Unlike the objective function used in Babad and Balachandran (1993), Alan and Gupta (1996) and Casten (2001), there is no need to calculate the optimal information using all the cost drivers first.

Equation 2 guarantees that the overall information cost for the $C L$ under consideration will not exceed the cost level budget, $B_{C L}$. Equation 3 guarantees that there will be at least one cost driver for the $C L$ under consideration such that number of cost drivers in that level will exceed a certain number of required cost drivers $n_{C L}$ in that level. Equation 4 demands that the budget for the $C L$ under consideration should be enough to choose at least one cost driver from that level. Equation 5 limits the values of the decision variable to binary values.

The costs of the cost drivers that will be omitted from the original set of the cost drivers will be allocated to the remaining cost drivers as follows: 


$$
\dot{A}_{C L_{i}}=A_{C L_{r}} \times \frac{A_{C L_{i}}}{\sum_{i \neq r} A_{C L_{i}}}+A_{C L_{i}}
$$

where $r$ is an index for the removed cost driver and $\dot{A}_{C L_{i}}$ is the new cost for cost driver $A_{C L_{i}}$ after adding its share from the removed cost driver $r$.

As this study deals with joint costing, the aforementioned CDO model must be applied at each cost level separately because the facility level cost must be allocated first to the various faculties using only facility level cost drivers. The allocated costs for the various faculties will be added to the separable costs of the corresponding faculties to form the joint cost for the different departments in the different faculties. Only after that, the product level cost can be allocated to the various departments using only product level cost drivers

\section{Methodology}

In this study, a model will be proposed to calculate the effective departmental credit-hour cost for different majors in the higher learning institutions by utilizing joint costing and $\mathrm{ABC}$ simultaneously. Optimal Cost drivers will be selected using a Knapsack setup to have a tradeoff between the precision and the cost of the information. The allocation of the University Overhead UOH cost to its different faculties will be considered as joint cost problem where $\mathrm{ABC}$ will be used to allocate it. In addition, the different departments within the faculty will be considered as a joint products and the total faculty overhead cost (consists of the allocated UOH cost and the separable Faculty Overhead cost FOH) will be allocated to the different departments using ABC analysis. Finally the Total Cost of the Department (TC) will be calculated by adding the following: its share from the Total University Overhead cost $(\mathrm{TUOH}=$ the allocated $\mathrm{UOH}$ and $\mathrm{FOH}$ costs to the department), the Department Overhead DOH cost (considered a separable cost for the department), and the Direct Labor DL cost in the department (considered also a separable cost for the department). This departmental total cost will be divided by the total annual effective credit-hours taught by the department in the underline fiscal year to have the annual effective departmental credit-hour cost for the fiscal year under consideration. The proposed model is shown in Figure 1.

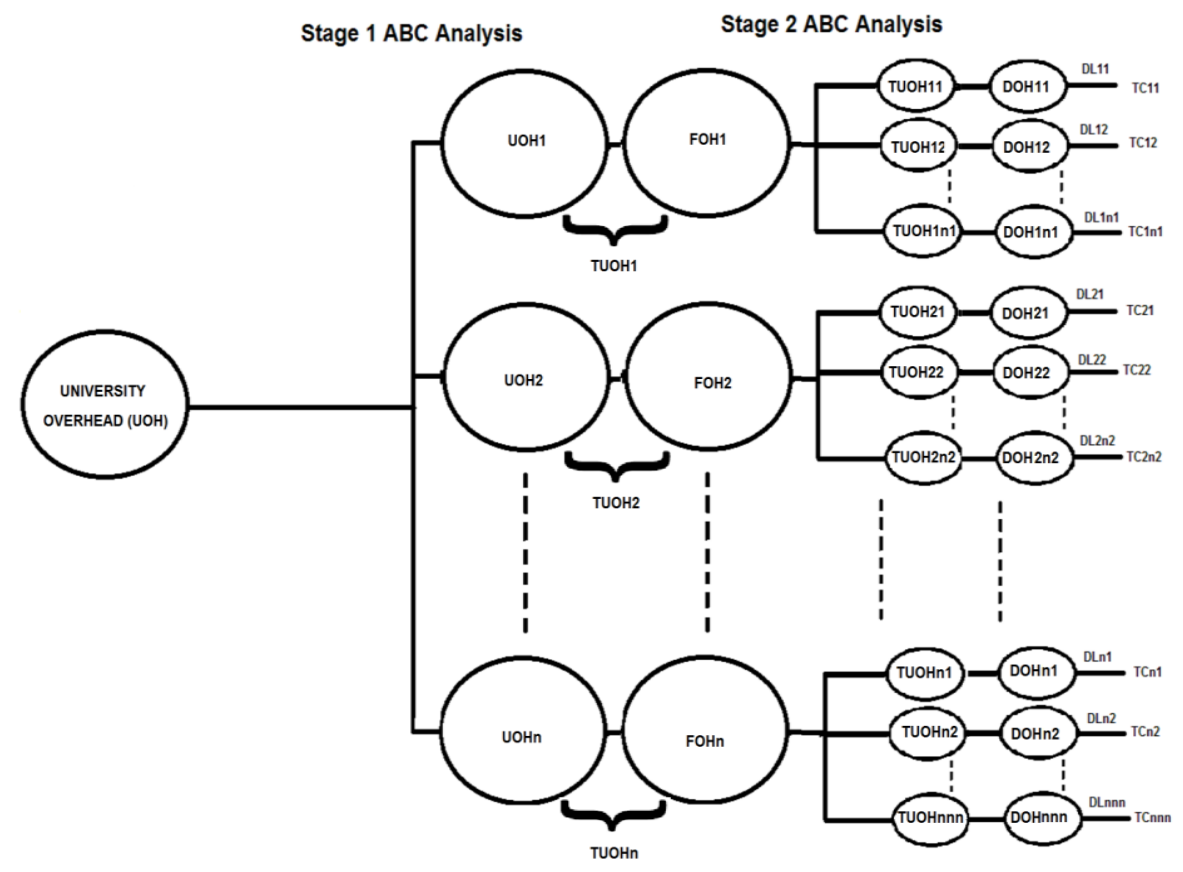

Figure 1. The breakdown of the total cost for the higher learning institution

Figure 2 shows a flow chart for the proposed methodology. 


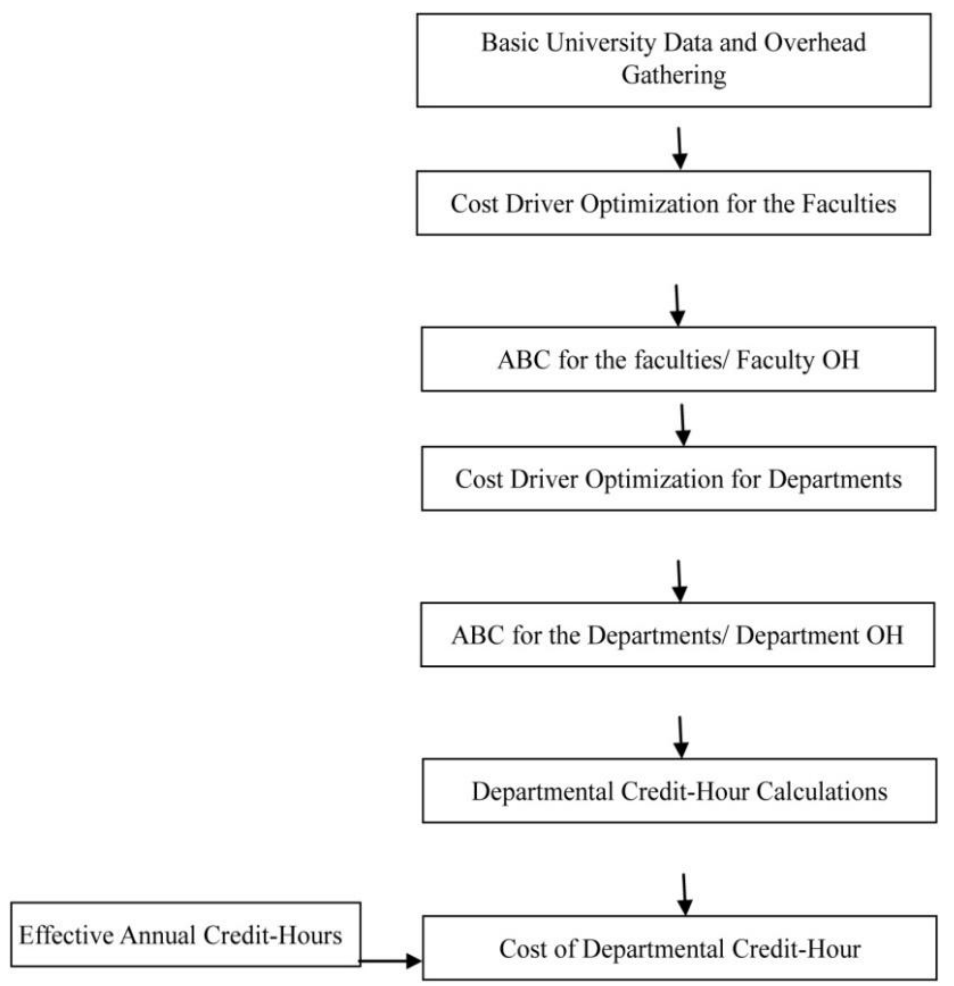

Figure 2. A flow chart for the proposed methodology

\section{Experimentation}

The proposed model will be explained using a hypothetical example of a university containing 9 faculties. The costs incurred on any higher learning institution can be decomposed into four levels as follows: Facility level and it includes all the costs that are not directly related to any of the faculties or departments, Product level and it includes all the costs that are related to a certain faculty and cannot be related to a specific department within that faculty, Batch level and it includes all the costs that are directly related to a specific department, and finally, the Unit level and it includes the annual effective number of hours registered in a department.

Originally 12 cost drivers will be considered as follows: 6 for Facility level (University level), 4 for Product level (Faculty level), 1 for Batch level (Department level), and 1for Unit level (Student level). Binary programming will utilize the Knapsack setup to select an optimal set of 9 cost drivers as follows: 4 for Facility Level, 3 for Product level, 1 for Batch level, and 1 for Unit level. Those cost drivers who are not selected will be combined with the ones that are selected according to equation 6.

The reason why Facility and Product levels have more cost drivers than Batch and Unit levels is that in the Batch and Unit Levels there is no diversity among the Units (students) so one cost driver should be enough to allocate the overhead cost precisely. For the Facility and Product levels, the diversity is high and so more cost drivers are needed to allocate the cost precisely. This reasoning coincides with what was discussed earlier in Cooper, 1990 about the relation between the number of cost drivers and the diversity in the products.

Furthermore, according to a study carried by Katrin and Tajana (2014), about 37\% of the respondents said that their universities used one to four cost drivers in their $\mathrm{ABC}$ systems. About $43 \%$ of the respondents said that five to nine are used, and $20 \%$ said that more than ten are used. The study concluded that five to nine cost drivers are usually used. So 9 cost drivers should be adequate for our analysis as about $80 \%$ of the respondents used less or equal to 9 cost drivers. This means that the Knapsack model will be used to select the optimal 9 cost drivers from the original 12 cost drivers to have a tradeoff between the precision of the results and the cost of doing the analysis. The 12 cost drivers are discussed next.

For the facility level (UOH), the following activity centers can be defined:

Activity Center 1: Safety and Security Department, Library Department, University Mosque, Banking Services, Olympic Stadium, Internet Services, Entertainment Centers, Computer Center, Internet Center, Financial 
Department, International Student Division, Higher Management Costs, Postal Services, and Transportation Cost. These activities seem to be related totally or partially to Support Centers.

Activity Center 2: Medical Services and Insurance, Students' Affair Division, Administration and Enrollment Division, Depreciation, Tenders and Purchases, Parking Lots, Computer Center, Financial Department, Internet Center, Library Department, Safety and Security Department, Banking Services, Transportation Cost, Internet Services, Sports Gym, Costs Incurred For the Mother Company, Postal services, and Higher Management Costs. These activities seem to be related totally or partially to Support Students.

Activity Center 3: Administrative Affairs, Catering, Faculty Development, Depreciation, Scientific Research, Medical Services and Insurance, Library Department , University Mosque, Parking Lots, Sports Gym, Banking Services, Internet Services, Entertainment Centers, Computer Center, Accreditation Department, Internet Center, Department Of Public and Foreign Relations, Higher Management Costs, Postal Services, and Financial Department. These activities seem to be related totally or partially to Support Faculty Members.

Activity Center 4: Department of Public and Foreign Relation, Tenders And Purchases, Accreditation Department, Studies Center, Arab Conference Center, E-Learning Center, Arbitration Center and Legal Advice, Higher Management Costs, Costs Incurred For the Mother Company, Scientific Research, and Safety and Security Department. These activities seem to be related totally or partially to Handle Faculties.

Activity Center 5: Medical Services and Insurance, University Mosque, Parking Lots, Sports Gym, Banking Services, Internet Services, Entertainment Centers, Computer Center, Internet Center, Financial Department, Transportation, Catering, Administration Affairs, Accreditation Department, Depreciation, Postal Services, and Higher Management Costs. These activities seem to be related totally or partially to Support Employees.

Activity Center 6: Maintenance, Energy Costs, and Safety and Security Department. These activities seem to be related totally or partially to Support Area.

For the product level (FOH), these activities include all the costs that are related to a specific faculty (separable cost to the faculty) and not related to a specific department (joint cost to the departments), the following activity centers can be defined:

Activity Center 7: Deans Office, Faculty Share of $\boldsymbol{U O H}$, Entertainment Expenses, Office Supplies, and Genitors Staff. These activities seem to be related totally or partially to Handle Secretary.

Activity Center 8: Deans Office, Faculty Share of $\boldsymbol{U O H}$, Entertainment Expenses, Office Supplies, and Genitors Staff. These activities seem to be related totally or partially to Handle Department.

Activity Center 9: Genitors Staff, Faculty Share of $\boldsymbol{U O H}$. These activities seem to be related totally or partially to Support Genitors.

Activity Center 10: Faculty Free Labs, Faculty Deans Office, Faculty Share of $\boldsymbol{U O H}$, Office Supplies, Faculty Library, and Genitors Staff. These activities seem to be related totally or partially to Handle Service Facilities.

For the Batch level (DOH), these activities include all the costs that are related to a specific department (separable cost to that department), the following activity center can be defined:

Activity Center 11: Faculty Members Salaries, Overtime, Secretary Office of the Department, Office Supplies for the Department, Genitors Staff for the Department, Representation Benefits, Department Labs. These activities seem to be related to Support Department.

For the Unit level we have Activity Center 12: the Annual Effective Hours Registered in the department. This activity seems to be related to Handle Effective hours.

A summary of the cost hierarch used for the 12 activity centers proposed in this paper is given in Table 1. It should be noticed here that under the joint costing schema adapted in this paper, the costs of the facility level activities are considered indirect costs to the different faculties in the higher learning institution. Furthermore, the costs of the product level activities are considered separable costs to the different faculties in the institution while they are considered joint costs to the different departments within these faculties. Also, the batch level activity is considered separable cost to the department, thus it is considered direct cost of the final product (credit-hour). Moreover, the unit level activity takes into consideration that not all credit hours registered by a certain major student are considered a cost on that department since students in certain major usually have to take courses outside their departments or even outside their faculties. Those credit hours taken outside the department should not be considered a cost on that department. 
Table 1. Higher learning institution activity centers

\begin{tabular}{lcc}
\hline Activity & Symbol & Cost hierarchy \\
\hline Support Centers & A1 & Facility Level \\
Support Students & A2 & Facility Level \\
Support Faculty Members & A3 & Facility Level \\
Support Employees & A4 & Facility Level \\
Support Area & A5 & Facility Level \\
Handle Faculties & A6 & Facility Level \\
Handle Secretary & A7 & Product Level \\
Handle Department & A8 & Product Level \\
Support Genitors & A9 & Product Level \\
Handle Service Facilities & A10 & Product Level \\
Support Department & A11 & Batch Level \\
Handle Effective hours & A12 & Unit Level \\
\hline
\end{tabular}

As mentioned earlier, the calculation details of the proposed model will be demonstrated using a university containing 9 faculties. The technical data used by this model is given in Table 2. The remaining financial data used by this model will be shown successively when needed.

Table 2. The university technical data needed for the proposed method

\begin{tabular}{|c|c|c|c|c|c|c|}
\hline Faculty & Department & $\begin{array}{l}\text { Number of } \\
\text { Students }\end{array}$ & $\begin{array}{l}\text { Credit } \\
\text { Hours }\end{array}$ & $\begin{array}{l}\text { Number of } \\
\text { Faculty } \\
\text { Members }\end{array}$ & $\begin{array}{c}\text { Number of Non } \\
\text { Academic } \\
\text { Employees }\end{array}$ & $\begin{array}{c}\text { Faculty } \\
\text { Area }\end{array}$ \\
\hline \multirow{5}{*}{$\begin{array}{l}\text { Faculty of Arts \& } \\
\text { Humanities }\end{array}$} & Department of Islamic Sharia and Law. & 85 & 136 & 6 & 3 & 800 \\
\hline & Department of Arabic language and Literature. & 103 & 136 & 13 & 4 & 860 \\
\hline & Department of English language and Literature. & 140 & 136 & 15 & 4 & 850 \\
\hline & Department of Education and Social Science & 106 & 136 & 13 & 5 & 750 \\
\hline & Department of Fine Arts. & 108 & 136 & 13 & 2 & 760 \\
\hline \multirow{10}{*}{$\begin{array}{c}\text { Faculty of } \\
\text { Economics \& } \\
\text { Administrative } \\
\text { Science }\end{array}$} & Department of Business Economics & 73 & 132 & 10 & 5 & 721 \\
\hline & Department of Accounting & 679 & 132 & 25 & 4 & 715 \\
\hline & Department of Business Administration & 150 & 132 & 13 & 2 & 742 \\
\hline & Department of Accounting in English & 570 & 132 & 25 & 3 & 736 \\
\hline & $\begin{array}{l}\text { Department of Management Information } \\
\text { Systems and E-Business }\end{array}$ & 156 & 132 & 14 & 4 & 842 \\
\hline & Department of Finance \& Banking & 325 & 132 & 14 & 3 & 826 \\
\hline & Department of Marketing & 212 & 132 & 18 & 3 & 743 \\
\hline & Department of Marketing in English & 110 & 132 & 13 & 3 & 716 \\
\hline & Department of Business Administration in English & 135 & 132 & 15 & 4 & 724 \\
\hline & Department of Finance \& Banking in English & 148 & 132 & 16 & 3 & 792 \\
\hline \multirow{6}{*}{$\begin{array}{l}\text { Faculty of } \\
\text { Engineering }\end{array}$} & Department of Computer Engineering & 230 & 160 & 7 & 3 & 738 \\
\hline & Department of Mechanical Engineering & 128 & 160 & 8 & 4 & 746 \\
\hline & Department of Industrial Engineering & 256 & 160 & 8 & 3 & 729 \\
\hline & Department of Civil Engineering & 690 & 160 & 16 & 3 & 719 \\
\hline & Department of Architecture Engineering & 420 & 167 & 13 & 3 & 763 \\
\hline & $\begin{array}{l}\text { Department of Electronics and Communications } \\
\text { Engineering }\end{array}$ & 130 & 160 & 10 & 3 & 768 \\
\hline
\end{tabular}




\begin{tabular}{|c|c|c|c|c|c|c|}
\hline \multirow{2}{*}{ Faculty of Law } & Department of Private Law & 121 & 141 & 3 & 3 & 762 \\
\hline & Department of Public Law & 128 & 141 & 3 & 4 & 722 \\
\hline \multirow{3}{*}{$\begin{array}{l}\text { Faculty of } \\
\text { Pharmacy }\end{array}$} & $\begin{array}{l}\text { Department of Department of Pharmaceutical } \\
\text { Sciences \& Pharmaceutics }\end{array}$ & 157 & 161 & 9 & 3 & 718 \\
\hline & $\begin{array}{l}\text { Department of Pharmaceutical Chemistry \& } \\
\text { Pharmacognosy }\end{array}$ & 320 & 161 & 9 & 4 & 766 \\
\hline & Department of Clinical Pharmacy \& Therapeutics & 215 & 161 & 11 & 3 & 816 \\
\hline \multirow{2}{*}{$\begin{array}{l}\text { Faculty of Allied } \\
\text { Medical Sciences }\end{array}$} & Department of Food Science \& Nutrition & 168 & 155 & 10 & 3 & 805 \\
\hline & Department of Basic Sciences & 175 & 155 & 11 & 3 & 803 \\
\hline \multirow{5}{*}{$\begin{array}{l}\text { Faculty of } \\
\text { Information } \\
\text { Technology }\end{array}$} & Department of Computer Science. & 135 & 132 & 10 & 3 & 833 \\
\hline & Department of Computer Information Systems. & 149 & 132 & 6 & 4 & 749 \\
\hline & Department of Software Engineering. & 121 & 132 & 5 & 3 & 788 \\
\hline & Department of Computer Network Systems. & 125 & 132 & 4 & 4 & 729 \\
\hline & Department of Master in Computer Science. & 154 & 132 & 4 & 3 & 769 \\
\hline \multirow{2}{*}{$\begin{array}{l}\text { Faculty of Art \& } \\
\text { Design }\end{array}$} & Department of Interior Design & 320 & 142 & 10 & 3 & 733 \\
\hline & Department of Graphic Design & 263 & 136 & 12 & 3 & 798 \\
\hline \multirow{3}{*}{$\begin{array}{l}\text { Faculty of } \\
\text { Nursing }\end{array}$} & $\begin{array}{l}\text { Department of Community Health Nursing } \\
\text { Department }\end{array}$ & 89 & 135 & 9 & 3 & 719 \\
\hline & Department of Clinical Nursing Department & 115 & 135 & 9 & 3 & 769 \\
\hline & $\begin{array}{l}\text { Department of Maternal and Child Health } \\
\text { Nursing Department }\end{array}$ & 11 & 135 & 10 & 3 & 756 \\
\hline Totals & & 7720 & 5385 & 420 & 126 & 29075 \\
\hline
\end{tabular}

The first step in $\mathrm{ABC}$ analysis is to trace the cost of the Resources to the Activity Centers to get the Activity Cost Pools. In the first stage of allocation, the $\mathrm{UOH}$ will be traced to the facility level activity centers to allocate the UOH to the different faculties in the institution. Table 3 shows how these resources can be traced to the different facility level activity centers and also shows the annual cost of resources for the university.

Table 3. First stage of tracing UOH to facility level activity centers

\begin{tabular}{|c|c|c|c|c|c|c|c|c|}
\hline Resources & Total Cost per year & A1 & A2 & $\mathbf{A 3}$ & A4 & A5 & A6 & Criterion \\
\hline $\begin{array}{c}\text { Medical Services and } \\
\text { Insurance }\end{array}$ & 18000 & & 0.5 & 0.3 & 0.2 & & & Ratio \\
\hline $\begin{array}{l}\text { Safety And Security } \\
\text { Department }\end{array}$ & 240000 & & 0.4 & & & 0.2 & 0.4 & Ratio \\
\hline Library Department & 20000 & 0.1 & 0.6 & 0.3 & & & & Judgment \\
\hline University Mosque & 20000 & 0.1 & & 0.3 & 0.6 & & & Judgment \\
\hline Parking Lots & 13000 & & 0.5 & 0.1 & 0.4 & & & Ratio \\
\hline Sports Gym & 16000 & & 0.5 & 0.1 & 0.4 & & & Ratio \\
\hline Banking Services & 13000 & 0.1 & 0.3 & 0.3 & 0.3 & & & Ratio \\
\hline Olympic Stadium & 10000 & 1 & & & & & & Judgment \\
\hline Internet Services & 160000 & 0.1 & 0.3 & 0.3 & 0.3 & & & Ratio \\
\hline Entertainment Centers & 13468 & 0.1 & & 0.3 & 0.6 & & & Ratio \\
\hline Computer Center & 32000 & 0.1 & 0.3 & 0.3 & 0.3 & & & Ratio \\
\hline Internet Center & 10000 & 0.1 & 0.3 & 0.3 & 0.3 & & & Ratio \\
\hline
\end{tabular}




\begin{tabular}{|c|c|c|c|c|c|c|c|c|}
\hline Financial Department & 131000 & 0.1 & 0.3 & 0.3 & 0.3 & & & Ratio \\
\hline $\begin{array}{c}\text { International Student } \\
\text { Division }\end{array}$ & 16000 & 1 & & & & & & Judgment \\
\hline Transportation & 98000 & 0.1 & 0.7 & & 0.2 & & & Ratio \\
\hline Student Affair Division & 24000 & & 1 & & & & & Judgment \\
\hline $\begin{array}{l}\text { Administration and } \\
\text { Enrollment Division }\end{array}$ & 55500 & & 1 & & & & & Judgment \\
\hline Depreciation & 75000 & & 0.3 & 0.3 & 0.4 & & & Ratio \\
\hline Administrative Affairs & 30000 & & & 0.6 & 0.4 & & & Ratio \\
\hline Catering & 10000 & & & 0.6 & 0.4 & & & Ratio \\
\hline $\begin{array}{l}\text { Faculty Development } \\
\text { Center }\end{array}$ & 16000 & & & 1 & & & & Judgment \\
\hline Value Development Center & 15000 & & & & & & 1 & Judgment \\
\hline $\begin{array}{l}\text { Department Of Public And } \\
\text { Foreign Relation }\end{array}$ & 1500000 & & & 0.5 & & & 0.5 & Judgment \\
\hline Tenders And Purchases & 13000 & & 0.5 & & & & 0.5 & Judgment \\
\hline Accreditation Department & 58000 & & & 0.33 & 0.33 & & 0.34 & Judgment \\
\hline Studies Centers & 15000 & & & & & & 1 & Judgment \\
\hline Arab Conference Center & 16795 & & & & & & 1 & Judgment \\
\hline E-Learning Center & 16000 & & & & & & 1 & Judgment \\
\hline $\begin{array}{l}\text { Arbitration Center And } \\
\text { Legal Advice }\end{array}$ & 13000 & & & & & & 1 & Judgment \\
\hline $\begin{array}{l}\text { The Higher Management } \\
\text { Costs }\end{array}$ & 100000 & & 0.1 & 0.1 & 0.2 & & 0.6 & Ratio \\
\hline Scientific Research & 750000 & & & 0.5 & & & 0.5 & Judgment \\
\hline Postal Services & 24000 & 0.1 & 0.3 & 0.3 & 0.3 & & & Ratio \\
\hline $\begin{array}{l}\text { Costs Incurred For The } \\
\text { Mother Company }\end{array}$ & 100000 & & 0.5 & & & & 0.5 & Judgment \\
\hline Maintenance & 1190000 & & & & & 1 & & Judgment \\
\hline Energy Costs & 762000 & & & & & 1 & & Judgment \\
\hline Total Activity Cost & 5593763 & 78147 & 479600 & 1351980.4 & 251020.8 & 2000001 & 1433015 & \\
\hline
\end{tabular}

\subsection{Optimal Cost Driver for Faculties}

Table 4 shows a summary of activity cost pools along with the information cost for the facility level activity centers.

Table 4. Activity cost pools for the facility level activity centers

\begin{tabular}{lcc}
\hline Activity Center & Activity Cost Pool $\left(\boldsymbol{C}_{f a(.)}\right)$ & $\mathbf{D}_{\mathrm{f}(\cdot)}$ \\
\hline Support centers & 78147 & 1500 \\
Support students & 479600 & 3250 \\
Support faculty members & 1351980 & 4600 \\
Support employees & 251020 & 1680 \\
Support Area & 2000000 & 3125 \\
Handle faculties & 1433015 & 2050 \\
\hline
\end{tabular}


The CDO set up to find the optimal activity cost drivers for the facility level by setting the required number of cost drivers $n_{f}$ to 4 and the facility level budget $B_{f}$ to $\$ 12000$ is as follows:

$$
\begin{gathered}
\operatorname{Max} 78147 x_{1}+479600 x_{2}+1351980 x_{3}+251020 x_{4}+2000000 x_{5}+1433015 x_{6} \\
\text { s.t } \\
1500 x_{1}+3250 x_{2}+4600 x_{3}+1680 x_{4}+3125 x_{5}+2050 x_{6} \leq 12000 \\
1 \leq x_{1}+x_{2}+x_{3}+x_{4}+x_{5}+x_{6} \leq 4 \\
x_{i} \text {, binary. }
\end{gathered}
$$

It should be noticed here that equation 4 in the model is satisfied as the facility level budget $B_{f}$ is greater than the minimum cost of gathering the information for the original cost drivers for the facility level and thus no need to rewrite it here. Running the CDO model on Excel Solver suggesting excluding cost drivers 1 and 2 (A1 and A2). This means that the costs for Support centers and Support employees cost drivers must be allocated to the remaining cost drivers using Equation 6. The resulting optimal set of cost drivers along with their costs are shown in Table 5.

Table 5. Optimal activity cost pools for the facility level activity centers

\begin{tabular}{lc}
\hline Activity Center & Activity Cost Pool $\left(\boldsymbol{C}_{\boldsymbol{f a}(.)}\right)$ \\
\hline Support faculty members & 1501714 \\
Support employees & 278822 \\
Support Area & 2221503 \\
Handle faculties & 1591724 \\
\hline
\end{tabular}

It must be notice here that even though Support students cost driver's cost is higher than Support employees cost driver cost, Support students cost driver was omitted due to its high cost of information.

\subsection{Joint Costing Allocation to Faculties}

The second step in $\mathrm{ABC}$ analysis is to trace the activity cost pools to their cost objects (Faculties) using appropriate activities cost drivers. Table 6 shows the activity cost drivers for the facility level activity centers along with their rates.

Table 6. Facility level activity centers and their cost drivers

\begin{tabular}{llc}
\hline Activity Center & Activity Cost driver & Rate $\left(\boldsymbol{R}_{f a(.)}\right)$ \\
\hline Support Faculty Members & Number of faculty members in faculty $i\left(m_{i}\right)$. & $R_{f a_{m i}}$ \\
Support Employees & Number of total employees in faculty $i\left(e_{i}\right)$ & $R_{f a_{e i}}$ \\
Support Area & Area of faculty $i\left(a_{i}\right)$ & $R_{f a_{a i}}$ \\
Handle Faculties & Number of faculties (n) & $R_{f a_{f}}$ \\
\hline
\end{tabular}

The equations for the rates used to allocate the $\mathrm{UOH}$ joint cost at its split off point to the different faculties in the university are as follows:

$$
\begin{gathered}
R_{f a_{m i}}=\frac{m_{i}}{\sum_{j=1}^{n_{i}} m_{i}}, i=1,2, \ldots, n \\
R_{f a_{e i}}=\frac{e_{i}}{\sum_{i=1}^{n} e_{i}}, i=1,2, \ldots, n \\
R_{f a_{a i}}=\frac{a_{i}}{\sum_{i=1}^{n} a_{i}}, i=1,2, \ldots, n \\
R_{f a_{f}}=\frac{1}{n}
\end{gathered}
$$


where $n$ is the total number of faculties in the university and $R_{f a(.)}$ is the rate for the corresponding facility level activity.

The allocated cost for the different faculties $U O H_{i}$ from the $U O H$ are calculated using the Activity Cost Pools of the facility level activities $C_{f a(.)}$ and their corresponding rates $R_{f a(.)}$ as follows:

$$
U O H_{i}=\sum_{f a=1}^{n_{f a}} R_{f a_{(.)}} \times C_{f a_{(.)}}, f a=1,2, . . n_{f a}, \forall i=1,2, \ldots, n
$$

Where $n_{f a}$ is the number of facility level activities in the optimal cost drivers set, i.e. $n_{f a}=4$ in this theoretical example.

For example, the allocated cost for Engineering Faculty $(i=3)$ can be calculated as follows:

$$
\begin{gathered}
\mathrm{UOH}_{3}=\sum_{f a=1}^{4} R_{f a_{(\cdot)}} \times C_{f a_{(\cdot)}} \\
=0.147619 \times 1501714+0.150794 \times 278822+0.153500 \times 2221503+0.111111 \times 1591 \\
=\$ 781584
\end{gathered}
$$

Table 7 shows the calculations of the allocated $U O H_{i}$ for the different faculties along with their total values.

Table 7. Calculations details for $U O H_{i}$

\begin{tabular}{lccccc}
\hline Faculty & $\mathbf{A 3}$ & $\mathbf{A 4}$ & $\mathbf{A 5}$ & $\mathbf{A 6}$ & $\mathbf{U O H}_{\mathbf{i}}$ \\
\hline Faculty of Arts \& Humanities & 214530.6 & 39831.71 & 307151.9 & 176858.2 & 738372 \\
Faculty of Economics \& Administrative Science & 582808.1 & 75237.68 & 577399.8 & 176858.2 & 1412304 \\
Faculty of Engineering & 221681.6 & 42044.59 & 340999.8 & 176858.2 & 781584 \\
Faculty of Law & 21453.06 & 15490.11 & 113386.4 & 176858.2 & 327187 \\
Faculty of Pharmacy & 103689.8 & 22128.73 & 175733.7 & 176858.2 & 478410 \\
Faculty of Allied Medical Sciences & 75085.7 & 13277.24 & 122860.8 & 176858.2 & 388081 \\
Faculty of Information Technology & 103689.8 & 37618.84 & 295538.2 & 176858.2 & 613705 \\
Faculty of Art \& Design & 78661.21 & 13277.24 & 116977.5 & 176858.2 & 385774 \\
Faculty of Nursing & 100114.3 & 19915.86 & 171455 & 176858.2 & 468343 \\
\hline
\end{tabular}

The next stage in the proposed model is to use $\mathrm{ABC}$ analysis to allocate the total faculty overhead, which consists of $\mathrm{UOH}_{i}$ and $\mathrm{FOH}_{i}$, to its different departments. First the total faculty overhead will be traced to the different product level activity centers. Table 8 shows the activity centers for this stage. It should be clear from

\begin{tabular}{|c|c|}
\hline Resources & Activity Center \\
\hline Deans Office, $\boldsymbol{U O H}_{i}$, Entertainment Expenses, Office Supplies, and Genitors Staff & Support Secretary \\
\hline Deans Office, $\boldsymbol{U} \boldsymbol{O} \boldsymbol{H}_{i}$, Entertainment Expenses, Office Supplies, and Genitors Staff & Support Department \\
\hline Genitors Staff, $\boldsymbol{U O H}_{\boldsymbol{i}}$ & Support Genitors \\
\hline Faculty Free Labs, Faculty Deans Office, $\boldsymbol{U O H}_{i}$, Office Supplies, Faculty Library, and Genitors Staff & Support Service Facilities \\
\hline
\end{tabular}
this table how $U O H_{i}$ is integrated in the faculties joint costs and accordingly allocated to the different departments within these faculties.

Table 8. Activity dictionary for stage 2

Table 9 shows the expense categories pertaining Engineering Faculty. It should be clear that the same analysis must be done to the other faculties. 
Table 9. Engineering faculty financial information pertaining second stage

\begin{tabular}{lc}
\hline Expense Category & Cost \\
\hline Deans Office Secretary & 12000 \\
$\boldsymbol{U O H}_{3}$ & 781584 \\
Entertainment Expenses & 1200 \\
Office Supplies & 1200 \\
Genitors Staff & 49200 \\
Faculty Free Labs & 12000 \\
Faculty Library & 5632 \\
\hline Totals & 862816 \\
\hline
\end{tabular}

Table 10 shows how the joint cost of a certain faculty can be traced to the different product level activity centers pertaining this faculty. The table shows the detailed calculations for Engineering Faculty.

Table 10. Second stage: Tracing total faculty indirect costs to product level activities

\begin{tabular}{lllllll}
\hline Expense Category & Cost & $\mathbf{A 7}$ & $\mathbf{A 8}$ & $\mathbf{A 9}$ & A10 & Notes \\
\hline Deans Office Secretary & 12000 & 0.33 & 0.33 & & 0.34 & Judgment \\
UOH3 & 781584.2 & 0.25 & 0.25 & 0.16 & 0.34 & Judgment \\
Entertainment Expenses & 1200 & 0.5 & 0.5 & & 0.34 & Judgment \\
Office Supplies & 1200 & 0.33 & 0.33 & 0.5 & 0.3 & Judgment \\
Genitors Staff & 49200 & 0.1 & 0.1 & & 1 & Judgment \\
Faculty Free Labs & 12000 & & & 1 & Judgment \\
Faculty Library & 5632 & & & 149653 & 302619 & \\
\hline Totals & 862816 & 205272 & 205272 & &
\end{tabular}

\subsection{Optimal Cost Driver for Departments}

Table 11 shows a summary of the Activity Cost Pools for the Product Level Activity Centers along with the information cost.

Table 11. Activity cost pools for the product level activity centers

\begin{tabular}{lll}
\hline Activity Center & Activity Cost Pool $\left(C_{d a(.)}\right)$ & $\mathbf{D}_{\mathrm{f}(\cdot)}$ \\
\hline Support Secretary & 205272 & 1350 \\
Support Department & 205272 & 2160 \\
Support Genitors & 149653 & 1985 \\
Support Service Facilities & 302619 & 2050 \\
\hline
\end{tabular}

The CDO set up to find the optimal activity cost drivers for the Department level by setting the required number of cost drivers $n_{p}$ to 3 and the facility level budget $B_{p}$ to $\$ 6000$ is as follows:

$$
\begin{gathered}
\operatorname{Max} 205272 x_{1}+205272 x_{2}+149653 x_{3}+302619 x_{4} \\
\text { s.t } \\
1350 x_{1}+2160 x_{2}+1985 x_{3}+2050 x_{4} \leq 6000 \\
1 \leq x_{1}+x_{2}+x_{3}+x_{4} \leq 3 \\
x_{i} \text {, binary. }
\end{gathered}
$$


It should be noticed here that equation 4 in the model is satisfied as the product level budget $B_{p}$ is greater than the minimum cost of gathering the information for the original cost drivers for the product level and thus no need to rewrite it here. Running the CDO model on Excel Solver suggests deleting activity 3 (A9). This means that its cost have to be allocated to the rest of the cost drivers according to Equation 6. The final activity cost pools for the product level is give in Table 12 .

Table 12. Optimal set of activity cost pools for the product level activity centers

\begin{tabular}{lc}
\hline Activity Center & Activity Cost Pool $\left(C_{d a(.)}\right)$ \\
\hline Support Secretary & 248347 \\
Support Department & 248347 \\
Support Service Facilities & 366122 \\
\hline
\end{tabular}

The second step in $\mathrm{ABC}$ analysis for this stage is to trace the costs from activity centers to departments using appropriate activities cost drivers. Table 13 shows the activities cost drivers for the product level activity centers along with their rates.

Table 13. Optimal product level activity centers and their cost drivers

\begin{tabular}{llc}
\hline Activity & Activity Cost driver & Rate $\left(R_{d a(.)}\right)$ \\
\hline Support Secretary & Number of departments in faculty $i\left(n_{i}\right)$ & $R_{d a_{d_{j}}}$ \\
Support Department & Number of faculty members in faculty $i\left(d m_{i}\right)$ & $R_{d a_{d m_{j}}}$ \\
Support Service Facilities & Number of students in faculty $i\left(d N_{i}\right)$ & $R_{d a_{d N_{j}}}$ \\
\hline
\end{tabular}

\subsection{Joint Costing for Departments}

The equations for the rates used to allocate the joint cost of total faculty overhead at their corresponding split off points to the different departments in the faculty are as follows:

$$
\begin{gathered}
R_{d a_{d_{j}}}=\frac{1}{n_{i}}, j=1,2, \ldots n_{i}, \forall i=1,2, \ldots, n \\
R_{d a_{d m_{j}}}=\frac{d m_{i j}}{d m_{i}}, j=1,2, \ldots n_{i}, \forall i=1,2, \ldots, n \\
R_{d a_{d N_{j}}}=\frac{d N_{i j}}{d N_{i}}, j=1,2, \ldots n_{i} \forall i=1,2, \ldots, n
\end{gathered}
$$

where $R_{d a(.)}$ is the rate for the corresponding product level activity and $d m_{i j} d N_{i j}$ are the number of faculty members and number of students in department $j$ of faculty $i$, respectively.

The allocated cost for the different departments from the total faculty overhead are calculated using the costs of the product level activities $C_{d a(.)}$ and their corresponding rates $R_{d a(.)}$ as follows:

$$
\operatorname{TUOH}_{i j}=\sum_{d a=1}^{n_{d a}} R_{d a_{(.)}} \times C_{d a_{(.)}}, d a=1,2, . . n_{d a}, \forall j=1,2, \ldots, n_{i}, \forall i=1,2, \ldots, n
$$

where $n_{d a}$ is the total number of product level activities, i.e. $n_{d a}=3$.

For example the allocated cost for Civil Engineering Department $(j=4)$ from Faculty of Engineering $(i=3)$ can be calculated as follows:

$$
\begin{gathered}
\text { TUOH }_{34}=\sum_{d a=1}^{3} R_{d a_{(.)}} \times C_{d a_{(.)}} \\
=0.166667 \times 307030+0.258065 \times 307030+0.372168 \times 445844=\$ 296334
\end{gathered}
$$


Table 14 shows the calculations of the allocated $T U O H_{i j}$ for the different departments in the Engineering Faculty along with their total values.

Table 14. Calculations details of $T U O H_{i j}$

\begin{tabular}{lcccc}
\hline Faculty of Engineering & \multicolumn{4}{c}{ Allocated Cost at second split off point } \\
\hline & A7 & A8 & A10 & TUOH \\
Department of Computer Engineering & 41391 & 28039 & 45420 & 114850 \\
Department of Mechanical Engineering & 41391 & 32045 & 25277 & 98713 \\
Department of Industrial Engineering & 41391 & 32045 & 50554 & 123990 \\
Department of Civil Engineering & 41391 & 64090 & 136259 & 241740 \\
Department of Architecture Engineering & 41391 & 52073 & 82940 & 176404 \\
Department of Electronics and Communications Engineering & 41391 & 40056 & 25672 & 107119 \\
\hline
\end{tabular}

The annual effective number of hours taught in the department can be found by subtracting any credit hours that were not taught in the department and were taken by students in that department and then adding any credit hours taught in the department for students from outside the department during the calendar year under consideration. The annual direct labor cost of the department can be found by adding up all the payments made such as Salaries and Overtime for the faculty members in the department during the calendar year under consideration. It can be calculated as

$$
D L_{i j}=\sum_{k=1}^{n_{i j}} D L_{i j k}, \forall i=1,2, \ldots, n \text { and } \forall j=1,2, \ldots, n_{i}, k=1,2, \ldots, n_{i j}
$$

Where $D L_{i j k}$ is the total annual payment for faculty member $k$ in department $j$ of faculty $i$ and $n_{i j}$ is the total number of faculty members in department $j$ of faculty $i$.

The annual direct cost for each department along with the annual effective number of hours taught in that department is given in Table 15. Table 16 shows a summary of costs pertaining different departments in the Engineering Faculty.

Table 15. The departmental technical data for the engineering faculty needed for the proposed method

\begin{tabular}{lccc}
\hline Department & DL & DOH & Annual Effective Number of Credit Hours $\left(h_{e i j}\right)$ \\
\hline Department of Computer Engineering & 168000 & 100000 & 5534.4 \\
Department of Mechanical Engineering & 192000 & 100000 & 3080.0 \\
Department of Industrial Engineering & 192000 & 100000 & 6160.0 \\
Department of Civil Engineering & 384000 & 100000 & 16603.3 \\
Department of Architecture Engineering & 312000 & 100000 & 10106.3 \\
Department of Electronics and Communications Engineering & 240000 & 100000 & 3128.1 \\
\hline
\end{tabular}

Table 16. Costs summary for engineering faculty departments

\begin{tabular}{|c|c|c|c|c|}
\hline Department & TUOH & $\mathrm{DOH}$ & DL & $\mathrm{TC}$ \\
\hline Department of Computer Engineering & 114850 & 100000 & 168000 & 382850 \\
\hline Department of Mechanical Engineering & 98713 & 100000 & 192000 & 390713 \\
\hline Department of Industrial Engineering & 123990 & 100000 & 192000 & 415990 \\
\hline Department of Civil Engineering & 241740 & 100000 & 384000 & 725740 \\
\hline Department of Architecture Engineering & 176404 & 100000 & 312000 & 588404 \\
\hline Department of Electronics and Communications Engineering & 107119 & 100000 & 240000 & 447119 \\
\hline
\end{tabular}




\subsection{Credit Hour Costing}

Next the departmental credit-hour cost for the fiscal year under consideration can be calculated as follows:

$$
H C_{i j}=\frac{T C_{i j}}{h_{e_{i j}}}, \quad j=1,2, \ldots n_{i} \forall i=1,2, \ldots, n
$$

Where $H C_{i j}$ is the departmental credit-hour cost for department $j$ of faculty $i$ for the fiscal year under consideration. $h_{e i j}$ is the total effective hours registered for department $j$ in faculty $i$ for the fiscal year under consideration and it includes all hours registered in that department for all students in the university regardless of their original departments. This information can be easily obtained from the registrar office depending on the different departments study plans. $T C_{i j}$ is the total cost for department $j$ in faculty $i$ for the fiscal year under consideration and it can be calculated as follows:

$$
T C_{i j}=T U O H_{i j}+D O H_{i j}+D L_{i j}, \forall j=1,2, \ldots, n_{i}, \forall i=1,2, \ldots, n
$$

where $T U O H_{i j}$ is the allocated Total University Overhead $\left(U O H_{i j}+F O H_{i j}\right)$ for department $j$ of faculty $i$ for the fiscal year under consideration, $D O H_{i j}$ is the overhead for department $j$ in faculty $i$ for the fiscal year under consideration, and $D L_{i j}$ is the direct labor of department $j$ of faculty $i$ for the fiscal year under consideration.

Table 17 shows a summary of the departmental credit-hour cost in the Faculty of Engineering for the fiscal year under consideration.

Table 17. The departmental credit-hour cost in the faculty of engineering

\begin{tabular}{lc}
\hline Department & Credit hour cost \\
\hline Department of Computer Engineering & 69 \\
Department of Mechanical Engineering & 127 \\
Department of Industrial Engineering & 68 \\
Department of Civil Engineering & 44 \\
Department of Architecture Engineering & 58 \\
Department of Electronics and Communications Engineering & 143 \\
\hline
\end{tabular}

Results obtained in Table 17 can be used to answer the fundamental accounting questions pertaining the institution, namely: How well did the departments perform? Where do the departments stand? How can the institution compete better in this business? And it can be used as a prediction base for fair tuition fees.

The results showed that the Civil Engineering Department had the lowest credit hour cost among the Engineering Faculty departments where Electronics and Communications Engineering Department had the highest credit hour cost. So the results suggest that the Civil Engineering Department is performing well while the Electronics and Communications Engineering Department needs improvement.

Assuming that the price charged for the credit hour in Engineering Faculty is $130 \$ / \mathrm{Hr}$, Civil Engineering Department is the most profitable department in the Engineering Faculty while Electronics and Communications Engineering Department is making loss and thus the 'close' decision should be explored for this department. Moreover, the Department of Industrial Engineering made a marginal profit of $62 \$ /$ Credit hour, this means that the top management can lower the credit hour price a little bit for this department to gain credit hour price competitive advantage that may increases the number of students in this department. The increase in the number of students may lower the credit hour cost. Depending on the increase in the students' numbers in this department, the overall profit of this department may increase. Moreover, this analysis may be used by the top management as a base for faculty member's incentives and salaries.

Knowing the precise cost of credit hour in the different departments call for different credit hour pricing for these departments within the same faculty. This means that some departments may have lower prices than $\$ 130 /$ credit hour and some departments may have higher price than $\$ 130$ /credit hour. This may increase the overall profit of the higher learning institution.

\section{Conclusions and Recommendations}

Many higher learning institutions are facing challenging competition because of their poor tuition pricing. A 
correct tuition pricing can give them a competitive advantage over similar institutions. For this purpose, a model is presented in this study to calculate the effective credit hour cost for different departments in higher learning institutions using Joint Costing and Activity-Based Costing systems simultaneously. This way of performing cost analysis provided the top managers with timely and quality information regarding How well did the departments perform? Where do the departments stand? And how can the institution compete better in this business? Moreover, this way also gave the top management a dependable way to measure the relative profitability of the different departments in their institutions. This matter helped the top management to know the profit generator from the loss generator departments thus helped them making keep and close decisions regarding the departments or salary-related and rewards decisions regarding faculty members.

As any other $\mathrm{ABC}$ analysis, qualitative measures (personal judgment) sometimes used to trace some elements of the overhead cost to the activities that consume them. These qualitative measures may reduce the creditability of the results obtained. A sensitivity analysis model that can quantify the effect of using such qualitative measures on the results obtained from the $\mathrm{ABC}$ analysis is needed to pinpoint those measures that most affect the results and replace them with quantitative measures. This may enhance the model and hence increases its credibility.

\section{Acknowledgment}

The authors are grateful to the Applied Science Private University, Amman, Jordan, for the full financial support granted to this research (Grant No. DRGS-2014).

\section{References}

Acton, D. D., \& Cotton, W. (1997). Activity - based costing in a university setting. Journal of Cost Management, March-April, 32-38.

Adams, M. (1996). Activity-based costing (ABC) and the life insurance industry. The Service Industries Journal, 16(4), 511-526. http://dx.doi.org/10.1080/02642069600000044

Alan, L., \& Mahesh, G. (1996). Using genetic algorithms to optimize the selection of cost drivers in activity-based costing. Intelligent systems in Accounting, Finance and Management, 5, 129-145. http://dx.doi.org/10.1002/(SICI)1099-1174(199609)5:3<129::AID-ISAF105>3.0.CO;2-S

Babad, Y., \& Balachandran, B. (1993). Cost driver optimization in activity-based costing. The Accounting Review, 68(3), 563-575.

Baird, K. M., Harrison, G. L., \& Reeve, R. C. (2004). Adoption of activity management practices: A note on the extent of adoption and the influence on organizational and cultural factors. Management Accounting Research, 15, 323-399. http://dx.doi.org/10.1016/j.mar.2004.07.002

Baykaso, G. A., \& Kaplano, G. V. (2008). Application of activity-based costing to a land transportation company: A case study. International Journal of Production Economics, 116(2), 308-324. http://dx.doi.org/10.1016/j.ijpe.2008.08.049

Bourn, M. (1994). Meeting the indirect costs of support services in universities: Top-slicing, charging-out, taxes, trading, and devolution. Financial Accountability \& Management, 10, 323-38. http://dx.doi.org/10.1111/j.1468-0408.1994.tb00155.x

Cagwin, D., \& Bouwman, M. J. (2002). The association between activity-based costing and improvement in financial performance. Management Accounting Research, 13, 1-39. http://dx.doi.org/10.1006/mare.2001.0175

Carlos, M. (2011). The applicability of the principles of activity-based costing system in a higher education institution. Economics and Management Research Projects: An International Journal, 1(1).

Casten, H. (2001). A note on optimal cost driver selection in ABC. Management Accounting Research, 12, 197-205. http://dx.doi.org/10.1006/mare.2000.0150

Cooper, R. (1989). The rise of activity-based costing — part three: How many cost drivers do you need, and how do you select them? Journal of Cost Management, 2(4), 34-46.

Cooper, R., \& Kaplan, R. (1988). Measure costs right: Make the right decisions. Harvard Business Review, 6, 96-103

Cox, K. S., Downey, R. G., et al. (2007). Activity-based costing and higher education: Can it work? Kansas State University.

Cropper, P., \& Cook, R. (2000). Activity-Based costing in universities: Five years on. Public Money and 
Management, 20, 61-68. http://dx.doi.org/10.1111/1467-9302.00213

Datar, S. M., Kekre, S., Mukhopadhyay, T., \& Srinivasan, K. (1993). Simultaneous estimation of cost drivers. The Accounting Review, 68, 602-614.

Dorota, K., \& Sabina, Z. (2011). Activity-based costing for health care institutions. $8^{\text {th }}$ International Conference on Enterprise Systems, Accounting and Logistics (8th ICESAL 2011) 11-12 July 2011, Thassos Island, Greece, pp. 300-311.

Foster, G., \& Swenson, D. W. (1997). Measuring the success of activity-based cost management and its determinants. Journal of Management Accounting Research, 9, 109-141.

Goddard, A., \& Ooi, K. (1998). Activity-based costing and central overhead cost allocation in universities: A Case Study. Public Money and Management, 18, 31-38. http://dx.doi.org/10.1111/1467-9302.00124

Hilton, R. W. (2005). Managerial accounting-Creating value in a dynamic business environment. New York: McGraw-Hill Irwin.

Innes, J., \& Mitchell, F. (1997). The application of activity-based costing in the United Kingdom's largest financial institutions. The Service Industries Journal, 17(1), 190-203. http://dx.doi.org/10.1080/02642069700000010

Jarrar, N., Smith, M., \& Dolley, C. (2007). Perceptions of preparers and users to accounting change: A case Study in an Australian university. Managerial Auditing Journal, 22, 80-94. http://dx.doi.org/10.1108/02686900710715657

Jordi, C., \& Xavier, S. (2008). Costing the banking services: A management accounting approach. Journal of Money, Investment and Banking, 6, 34-53.

Katrin, T., \& Tatjana, P. (2014). Theoretical framework and an overview of the cost drivers that are applied in universities for allocating indirect costs. Procedia-Social and Behavior Sciences, 110, 1014-1022. http://dx.doi.org/10.1016/j.sbspro.2013.12.948

Krishnan, A. (2006). An application of activity based costing in higher learning institution: A local case study. Contemporary Management Research, 2(2), 75-90.

McGowan, A., \& Klammer, T. (1997). Satisfaction with activity-based cost management implementation. Journal of Management Accounting Research, 9(Fall), 217-238.

Robert, S. K. (1992). In defense of activity-based cost management. Management Accounting, 74(5), 58-63.

Ruhupatty, L. R., \& Ben, A. M. (n. d). Using the activity-based costing approach to measure the cost of quality in higher education: A faculty perspective. Retrieved May 7, 2014 from http://ijmit.org/index.php/ijmit/article/viewFile/149/157

Wang, P., Du, F., Lei, D., \& Lin, T. (2010). The choice of cost drivers in activity-based costing: Application at a Chinese oil well cementing company. International Journal of Management, 27(2), 367-380.

\section{Copyrights}

Copyright for this article is retained by the author(s), with first publication rights granted to the journal.

This is an open-access article distributed under the terms and conditions of the Creative Commons Attribution license (http://creativecommons.org/licenses/by/3.0/). 